\title{
Proposal of public policies regarding the mental and emotional health of the population
}

\author{
Panait (Loghin) Claudia Daniela \\ Master of Management of Public Institutions (Faculty of Law and Administrative \\ Sciences - "Ovidius" University of Constanta, Romania) \\ claudialoghin1975@gmail.com
}

\section{Volume coordinators}

Prof. univ. dr. habil. Mihaela Rus

"Ovidius" University of Constanta (Faculty of Law and Administrative Sciences)

psiholog_m@yahoo.com

\section{Lect. univ. dr. Mihaela Sandu}

"Ovidius" University of Constanta (Faculty of Psychology and Educational Sciences) mihaela_naidin@yahoo.com

\author{
Asist. univ. dr. Tănase Tasențe \\ "Ovidius" University of Constanta (Faculty of Law and Administrative Sciences) \\ office@pluscommunication.eu
}

\begin{abstract}
A percentage of $13 \%$ of EU citizens are affected, at some point in their life, by depression. Paradoxically, Romanians are among the happiest Europeans, despite constant economic difficulties. However, surveys show that people are increasingly worried, suffering from anxiety, depression and stress. A recent study shows that $20 \%$ of Romanians suffer from mental disorders. Most are adults who have problems in professional life, in society, in the family. Such patients are always sad, without desire for life, they are withdrawn, they do not want to socialize. Anxiety is the main disease suffered by Romanians and even people around the world. Romanians are afraid of the economic crisis, corruption, poverty, climate change, terrorist attacks, crime. The objective of the public policy proposal is to approach with priority the mental and emotional health of the people in Romania.
\end{abstract}

Keywords. Mental and emotional health, public policy, Romania 


\begin{tabular}{|c|c|}
\hline $\begin{array}{l}\text { The initiating } \\
\text { institution }\end{array}$ & $\begin{array}{c}\text { Ministry of Labor and Social Justice } \\
\text { Ministry of Education } \\
\text { Ministry of Health } \\
\text { Youth and Sports Ministry }\end{array}$ \\
\hline $\begin{array}{c}\text { The cause of the } \\
\text { problem }\end{array}$ & $\begin{array}{l}\text { A percentage of } 13 \% \text { of EU citizens are affected, at some point in their life, } \\
\text { by depression. Paradoxically, Romanians are among the happiest Europeans, } \\
\text { despite constant economic difficulties. } \\
\text { However, surveys show that people are increasingly worried, suffering from } \\
\text { anxiety, depression and stress. A recent study shows that } 20 \% \text { of Romanians } \\
\text { suffer from mental disorders. Most are adults who have problems in } \\
\text { professional life, in society, in the family. Such patients are always sad, } \\
\text { without desire for life, they are withdrawn, they do not want to socialize. } \\
\text { Anxiety is the main disease suffered by Romanians and even people around } \\
\text { the world. Romanians are afraid of the economic crisis, corruption, poverty, } \\
\text { climate change, terrorist attacks, crime. } \\
\text { It is no longer news that women are more worried than men. It seems that } \\
\text { women are twice as affected by anxiety than men. Many cases also occur } \\
\text { among people aged } 18 \text { and over. More than } 20 \% \text { of Romanians believe that } \\
\text { nothing works well in Romania. } \\
\text { More than } 2 \text { million Romanians have depressed states, created by worries, } \\
\text { financial problems, family conflicts, shortcomings of life, stressful daily } \\
\text { events. } \\
\text { In our country, children also suffer from depression due to divorces of their } \\
\text { parents and the fact that their parents went to work abroad. Romanians suffer } \\
\text { from depression, mainly because of their dissatisfaction with the way they } \\
\text { live, because of the emotional breakdowns they experience, the dark } \\
\text { thoughts and disorders of adaptation to stressors. They can aggravate their } \\
\text { condition and against the background of factors that favor the disease: } \\
\text { alcohol consumption, caffeine, smoking, hormonal imbalances, exaggerated } \\
\text { drug use, certain stressful situations that recur frequently and others. } \\
\text { Until now, in Romania, depression was not considered a disease that would } \\
\text { need a government program to combat it. This, although the estimated } \\
\text { number of patients is the same as in the case of diabetics. } \\
\text { If left untreated, depression can lead to suicide, and statistics show us once } \\
\text { again concerning numbers, such as one million suicides a year in the world } \\
\text { because of this condition. }\end{array}$ \\
\hline $\begin{array}{r}\text { Nam } \\
\text { p }\end{array}$ & $\begin{array}{l}\text { Proposal of public policies regarding the mental and emotional health of the } \\
\text { population }\end{array}$ \\
\hline Purpose & $\begin{array}{l}\text { The intention of the Romanian Government is that through its social and } \\
\text { educational policies, it will focus on the prevention and alleviation of mental } \\
\text { illness, which could improve the results of education and increase labor } \\
\text { productivity. Depression is expensive because of the large number of people } \\
\text { affected and the major impact on the workforce. In order to increase people's } \\
\text { working time, actions against depression and mental disorders are crucial. }\end{array}$ \\
\hline $\begin{array}{l}\text { General } \\
\text { objective / } \\
\text { Specific } \\
\text { objectives }\end{array}$ & $\begin{array}{l}\text { General objective: to approach people's mental and emotional health with } \\
\text { priority } \\
\text { Specific objectives: } \\
\text { 1. Estimating the age of onset of the main mental and emotional } \\
\text { disorders, especially depression and anxiety }\end{array}$ \\
\hline
\end{tabular}




\begin{tabular}{|c|c|c|}
\hline & \multicolumn{2}{|c|}{$\begin{array}{l}\text { 2. Prevention services to be provided in schools, homes and } \\
\text { communities against child abuse and bullying, building resilience and } \\
\text { creating socio-emotional skills and abilities to deal with } \\
\text { disadvantaged situations, avoiding stigma and discrimination } \\
\text { 3. Prevention services provided to groups: socio-professional } \\
\text { reintegration programs, support groups for depression, anxiety, } \\
\text { mental disorders } \\
\text { 4. Promoting a positive school climate } \\
\text { 5. Modernize the financing of healthcare, including free social } \\
\text { psychotherapy services } \\
\text { 6. Supporting the coordinated workforce } \\
\text { 7. Promote the efficient use of technology } \\
\text { 8. Promoting health in the workplace, including stress management } \\
\text { 9. Healthy eating } \\
\text { 10. 10. Integration of sport into periodic activities }\end{array}$} \\
\hline Ben & $\begin{array}{l}\text { 1. Direct: adolescents, yo } \\
\text { attacks, anxiety, depressi } \\
\text { 2. Indirect: parents, te } \\
\text { psychologists, NGOs, ci }\end{array}$ & $\begin{array}{l}\text { ung population, people who have panic } \\
\text { on, mental disorders } \\
\text { achers, doctors, nutritionists, athletes, } \\
\text { vil society }\end{array}$ \\
\hline & 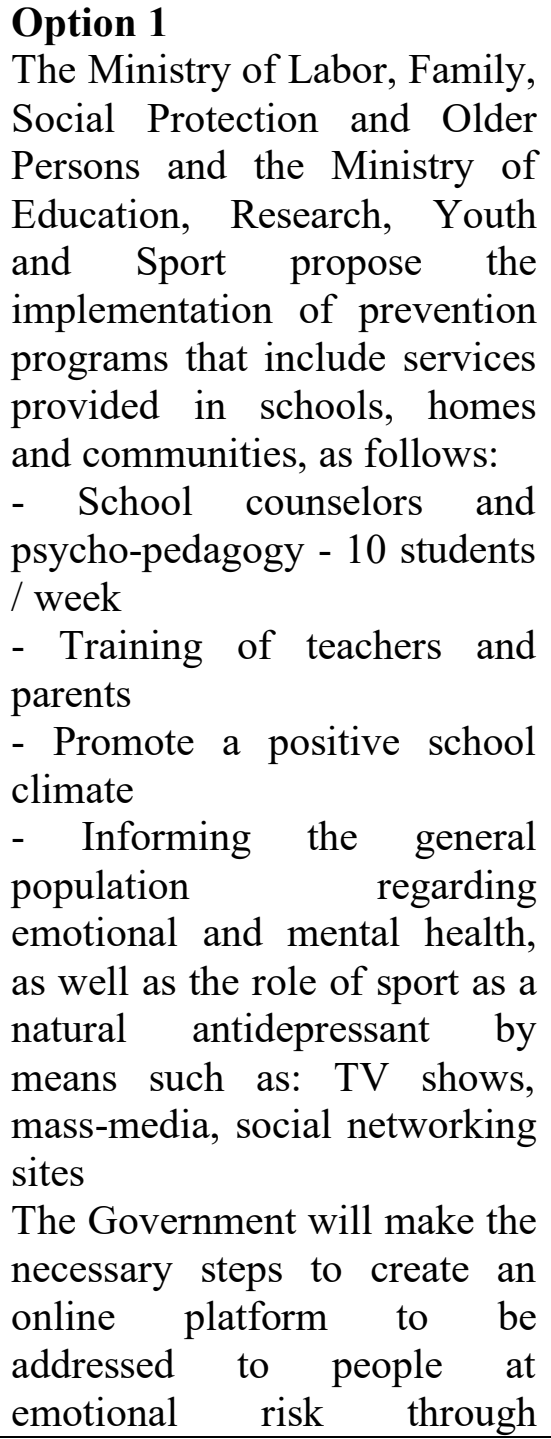 & $\begin{array}{l}\text { Impact } 1 \\
\text { The direct impact is to realize that without } \\
\text { mental and emotional health there is no } \\
\text { health, that by preventing and working } \\
\text { together several types of institutions reduce } \\
\text { unnecessary and unsafe services and } \\
\text { treatments. } \\
\text { The importance of the cognitive baggage } \\
\text { that school provides to the student is not } \\
\text { questionable, but as equally important is } \\
\text { the availability and freedom to let the } \\
\text { student get to know themselves, to express } \\
\text { themselves without being discouraged, to } \\
\text { enrich their emotional universe. } \\
\text { Involving civil society in developing } \\
\text { recommendations and integrating mental } \\
\text { health issues, preventing reducing } \\
\text { substance use, improving education } \\
\text { outcomes and increasing work } \\
\text { productivity. }\end{array}$ \\
\hline
\end{tabular}


multidisciplinary services:

- evaluation, diagnosis and treatment online and do-to-do;

- free social psychotherapy services;

- awareness workshops and relapse prevention;

- support groups for depression, anxiety, panic attacks;

- nutritional, sports, legal, vocational counseling;

- alternative techniques and therapies;

- socio-professional reintegration programs.

For exceptional cases where there will be no access to the use of the platform in a time horizon, information support will be provided through brochures and campaigns with various partner NGOs.

\section{Benefits:}

- Students will have permanent access to information accredited in the field;

- Offering an alternative prevention, regardless of the administrative and financial problems of the population - Development of a rich social life, involvement in family activities, tasks and domestic responsibilities;

- Forming a horizon of understanding and stage-based knowledge, according to the interests of the age;

\section{Risks:}

- Attitude of certain persons (parents, teachers, etc.) who do not consider physical and emotional health a priority - Lack of school counselors and psycho-pedagogues, as 
well as specialists in the field - Difficulty of teachers to adapt to students, school syllabus, etc.

- Lack of interest in integrating mental health into the healthcare system

\section{Option 2}

Organizing, periodically, informative sessions on the mental and emotional health of community members.

Students will be able to receive the desired information, leaflets, brochures that address various topics in the field.

Also, educating the workplace about mental health in order to prevent individuals from battling depression in silence and to increase their engagement in the community, given that communities can have more control over their resources and can help more people.

Organizing webinars - as a source of information about the areas that matter for mental health.

\section{Benefits:}

- Informing citizens;

- Awareness of the problem and the need to approach it;

- the health care system that promotes recovery no longer treats mental illness as a lifelong disability

\section{Risks:}

- Attitude of certain persons (parents, teachers, etc.) who do not consider physical and emotional health a priority - Lack of school counselors and psycho-pedagogues, as well as specialists in the field - Lack of interest in integrating
The direct impact would be to understand the role of each in improving the mental and emotional health of the population, starting from the premise that over $50 \%$ of Romanians suffering from depression do not know they have this condition, and of those who know, less than $1 / 3$ request professional help. 


\begin{tabular}{|c|c|}
\hline & $\begin{array}{l}\text { mental health into the } \\
\text { healthcare system }\end{array}$ \\
\hline $\begin{array}{l}\text { The } \\
\text { consultation } \\
\text { process }\end{array}$ & $\begin{array}{l}\text { Organizations, institutions consulted: } \\
\text { 1. Save the Children Romania } \\
\text { 2. National College of Psychologists in Romania } \\
\text { 3. Mindfulness Teachers Association } \\
\text { 4. The National Federation of Parents' Associations in Romania } \\
\text { 5. Development association for social assistance and vocational training } \\
\text { The result of the consultation: } \\
\text { 1. Problems arising in communication with some institutions due to } \\
\text { bureaucracy } \\
\text { 2. Accepting the granting of support in carrying out and ensuring the } \\
\text { development of the project in accordance with the legislative } \\
\text { provisions in this field. } \\
\text { 3. Attracting a large number of advisers and specialists in all areas } \\
\text { covered by this public policy }\end{array}$ \\
\hline $\begin{array}{l}\text { Recommended } \\
\text { solution }\end{array}$ & $\begin{array}{l}\text { Alternative I is the most beneficial option especially for children, adolescents } \\
\text { and young people in the sense that the school represents a huge potential for } \\
\text { the emotional enrichment of the child, teenager and future adult in order to } \\
\text { acquire skills through non-formal education techniques. and informal, as } \\
\text { well as in order to proactively improve their mental health with } \\
\text { consequences for their direct involvement, subsequently, in society. Also, a } \\
\text { number of non-governmental organizations and sports associations can } \\
\text { support this public policy through their own programs to improve the quality } \\
\text { of life. }\end{array}$ \\
\hline
\end{tabular}

